\title{
Delineation and Mapping of Soil Available Zinc and Boron Status in Soils of Vellore District of Tamil Nadu, India
}

\author{
Soniya Purma ${ }^{1 *}$, D. Muthumanickam ${ }^{2}$ and M. R. Reshma ${ }^{3}$ \\ ${ }^{1}$ AICRP on Micro \& Secondary Nutrients and Pollutant Elements in Soils and Plants, \\ Hyderabad Centre, India \\ ${ }^{2}$ Department of Soil Science and Agricultural Chemistry, Tamil Nadu Agricultural \\ University, Coimbatore, Tamil Nadu, India \\ ${ }^{3}$ Department of Soil Science and Agricultural Chemistry, Kerala Agricultural \\ University, India \\ *Corresponding author
}

\section{A B S T R A C T}

\section{Keywords}

Di-Ethylene TriAmine Penta Acetic Acid (DTPA), Hot

Water Soluble, Nutrient Index Values, Fertility Ratings and Thematic Maps

\section{Article Info}

\section{Accepted:} 20 December 2020 Available Online: 10 January 2021
The study was conducted in soils of Vellore district of Tamil Nadu to delineate the soil available zinc and boron status. Totally 3010 soil samples were collected @ 4 samples per village covering 743 panchayat villages in 20 blocks of Vellore district. Samples were collected randomly at $0-15 \mathrm{~cm}$ depth and the GPS data (Latitude ${ }^{\circ} \mathrm{N}$ and Longitude ${ }^{\circ} \mathrm{E}$ ) were recorded from each sampling site. Soil samples were analyzed for DTPA-Zn (Diethylene Tri-amine Penta Acetic acid extractable Zinc) and HWS-B (Hot Water Soluble Boron). The availability of zinc and boron in the soils of Vellore was marginal pertaining to fertility status. The analytical results were used for calculating per cent deficiency, nutrient index values and fertility ratings. The thematic maps were generated to show the extent of micronutrients deficiency or sufficiency based on block mean, nutrient index values and spatial variability. Deficiency of $\mathrm{Zn}$ was noticed in Jolarpet, Tiruppathur and Madhanur blocks which demands suitable management strategies for zinc nutrition of crops. Next to Zn, B deficiency was evidenced significantly in certain villages of Sholinghur block. A totally 44.3 per cent of the samples were found to be Zn deficient and 29.1 percent of the samples were found to be B deficient. The fertility rating class for $\mathrm{Zn} \&$ $\mathrm{B}$ is marginal for which nutrient index values are 1.86 for zinc and 1.91 for boron.

\section{Introduction}

Micronutrients fertilization is as important as macronutrient fertilization even though it is required in less quantity. The deficiency of micronutrients leads to plant abnormalities, reduced growth and lower yield. Deficiency of micronutrients in soils and plants is a global nutritional problem and is prevalent in many countries with variation in magnitude of severity. Deficiency of micronutrients has grown in both, magnitude and extent due to 
increased use of high analysis fertilizers, adoption of high yielding crop varieties and increased cropping intensity. The deficiency may either be primarily due to their low contents or secondarily by soil factor that reduce the availability (Sharma and Chaudhary, 2007). Deficiency of $\mathrm{Zn}$ covers the largest area in India and deficiency of B is common in coarse textured, low organic matter soils occurring in high rainfall regions.

In the present era of precision farming, the inputs are applied as per the location specific requirements of the crop. Systematic collection of georeferenced samples and preparation of spatial data for the distribution of nutrients is possible using Global Positioning System (GPS) and Geographical Information System (GIS) tools. Spatial variability analysis of nutrients is one of the key factors for precision agricultural management. To assess the variability of soil nutrients, geostatistical methods can be used (Mueller et al., 2003). The spatial variability achieved through the analysis of the function of spatial covariance and also estimated the values for unsampled locations without bias and with minimum variance. Thus the study of spatial variability of soil micronutrients data promotes support for the rational management of soil with the objective of the sustainable agricultural environment.

\section{Materials and Methods}

Vellore district has total geographical area of $5920.18 \mathrm{~km}^{2}$. Vellore district is bounded by Chittor (Andhra Pradesh) and Tiruvallur district on North, Tiruvannamalai district on south, Kancheepuram district on the east and Dharmapuri district on the west. The district lies between $12^{\circ} 15^{\prime}$ and $13^{\circ} 15^{\prime}$ North latitude and between $78^{\circ} 20^{\prime}$ and $79^{\circ} 50^{\prime}$ of the east longitude. This district is composed of seven taluks namely, Arakkonam, Arcot, Gudiyattam, Tiruppathur, Kaniyambadi,
Vellore and Walajapet, comprising of twenty blocks viz., Arakkonam, Kaveripakkam, Nemili, Arcot, Timiri, Gudiyattam, Katpadi, K.V.Kuppam, Peranambattu, Jolarpet, Kandili, Natrampalli, Tiruppathur, Alangayan, Madhanur, Anaicut, Kaniyambadi, Vellore, Sholinghur and Walajapet with 743 panchayat villages.

Totally 3010 geo-referenced surface soil samples were collected at the rate of 4 numbers per Panchayat village randomly at 0 $15 \mathrm{~cm}$ depth by adopting the standard procedures of soil sample collection. These soil samples are air dried, sieved $(2 \mathrm{~mm})$ and analyzed. Locations of soil sampling sites of Vellore district were marked on base map on 1:50,000 scales prepared from State Revenue Maps and digitized using Arc-info GIS. Apart from these GPS data, the basic data such as crop stand in the soil sampling site, major crops cultivated in that locality, system of cultivation, fertilization practices and source of irrigation were also collected.

The available $\mathrm{Zn}$ was extracted with DTPA extraction method (Lindsay and Norvell, 1978) using Atomic Absorption Spectrometer. The available B status of the soil was estimated using hot water as extractant (Berger and Troug, 1946). The soil samples were categorized into low, medium and high categories based on the critical limit of available $\mathrm{Zn}$ and B (Table 1). The deficiency per cent sample at each category was assessed for all elements at block level. Nutrient index values were calculated from the proportion of soils under low, medium and high available nutrient categories, as represented by

$\mathrm{NIV}=\left[\left(\mathrm{PH}^{*} 3\right)+\left(\mathrm{PM}^{*} 2\right)+(\mathrm{PL} * 1)\right] / 100$

Where, NIV $=$ the nutrient index value

PL, PM and PH are the percentage of soil samples falling in the category of low, 
medium and high nutrient status and given weight age of one, two and three respectively (Ramamurthy and Bajaj, 1969). The index values are rated in to various categories viz., very high (>2.67), high (2.33 to 2.67), adequate (2.00 to 2.33), marginal (1.67 to $2.00)$, low (1.33 to 1.67$)$ and very low $(<1.33)$ for fertility rating.

The Vellore district map (1:50,000) was vectorised by using Raster to Vector software (R2V), and then exported into Arc-GIS software. Database on available soil zinc and available boron status of the study area was developed using Microsoft Excel package and then this database was exported to Arc-GIS software. In the present investigation, linear directional semivariogram is constructed for available $\mathrm{Zn}$ and $\mathrm{B}$ in spatial dependent models by plotting the semi-variance is a function of $\log$ between neighbouring observations.

\section{Results and Discussion}

The DTPA-Zn status of the soils ranged from 0.10 to $11.4 \mathrm{mg} \mathrm{kg}-1$ with a mean of $1.8 \mathrm{mg}$ $\mathrm{kg}^{-1}$ (Table 2). Most of the soils were found to be deficient in $\mathrm{Zn}$ status based on critical value of $1.2 \mathrm{mg} \mathrm{kg}^{-1}$ with lower range starting from as low as $0.10 \mathrm{mg} \mathrm{kg}^{-1}$ in the soils of Kaveripakkam, Peranambattu, Tiruppathur, Vellore and Walajapet blocks. The mean value showed that available $\mathrm{Zn}$ was the highest in Alangayan $\left(11.4 \mathrm{mg} \mathrm{kg}^{-1}\right)$ followed by Arcot block (11.1 mg kg-1). The lowest mean available $\mathrm{Zn}$ content was observed in Jolarpet $\left(1.0 \mathrm{mg} \mathrm{kg}^{-1}\right)$, Tiruppathur $(0.5 \mathrm{mg}$ $\mathrm{kg}^{-1}$ ) and Madhanur (1.1 $\left.\mathrm{mg} \mathrm{kg}^{-1}\right)$.

The per cent sample category for DTPAextractable Zinc was classified under low, medium and high category based on critical limits. The results showed that 44.3, 21.9 and 33.9 per cent of total samples were under low, medium and high category respectively
(Table.2). Out of the 20 blocks, the highest percentage of deficient samples were found in Tiruppathur $(98.4 \%)$ block followed by Jolarpet $(79.0 \%)$ and Madhanur (73.1 \%) blocks. Lesser percentage of deficient samples was found in Gudiyattam block (11.1 $\%)$.

The nutrient index value for $\mathrm{Zn}$ in the soils of Vellore district ranged from 1.01 to 2.55 with a mean of 1.86 which indicated that the soils were marginal in $\mathrm{Zn}$ fertility (Table 2). Among the blocks, Gudiyattam block registered the high (2.55) Zn fertility status while very low fertility status was shown by Nemili and Tiruppathur blocks with index values of 1.01 and 1.02 respectively. The low availability of $\mathrm{Zn}$ content in the investigated soils of some blocks might be due to the low $\mathrm{OC}$ in these blocks.

The results of the present investigation are in conformity with those of Takkar et al., (1997) who envisaged that when the soils are low in organic matter and not supplemented by mineral fertilization they are prone to zinc deficiency. Based on nutrient index values fertility map for $\mathrm{Zn}$ was prepared using Arc GIS software (Figure 1).

The soils of Vellore district were found to have deficient to sufficient boron availability and it ranged from 0.1 to $7.4 \mathrm{mg} \mathrm{kg}$ - 1 with a mean of $0.72 \mathrm{mg} \mathrm{kg}^{-1}$ (Table 3). The highest boron availability content was noticed in the soils of Natrampalli $\left(7.4 \mathrm{mg} \mathrm{kg}^{-1}\right)$ followed by Kandili blocks $\left(5.9 \mathrm{mg} \mathrm{kg}^{-1}\right.$ ) The high boron availability in these regions might be due that much of the boron in soil is associated with organic matter in tightly bound compounds and released as available form upon microbial action (Siba et al., 2002). High levels of boron in soils might be due to naturally high concentrations of boron in soils or the use of irrigation water containing high in soluble salts of boron (Bradford 1966). 
Table.1 Critical Limits for the Soil Samples Categorization into Different Fertility Classes

\begin{tabular}{|l|c|c|c|c|}
\hline \multicolumn{2}{|c|}{ Element } & \multicolumn{3}{c|}{ Category } \\
\cline { 3 - 5 } \multicolumn{2}{|c|}{} & Low & Medium & High \\
\hline Zinc $(\mathbf{Z n})$ & $(\mathrm{mg} / \mathrm{kg})$ & $<1.2$ & $1.2-1.8$ & $>1.8$ \\
\hline Boron $(B)$ & & $<0.46$ & $0.46-1.0$ & $>1.0$ \\
\hline
\end{tabular}

Table.2 Range, Mean Values, Percent Sample Category, NIV and Fertility Rating of DTPA-Zn for all the Blocks in Vellore District

\begin{tabular}{|c|c|c|c|c|c|c|c|c|c|}
\hline \multirow[t]{2}{*}{ S.No } & \multirow{2}{*}{$\begin{array}{c}\text { Name of the } \\
\text { Block }\end{array}$} & \multirow{2}{*}{$\begin{array}{c}\text { No. of } \\
\text { Samples } \\
\text { Collected }\end{array}$} & \multirow[t]{2}{*}{ Range } & \multirow{2}{*}{$\begin{array}{c}\text { Mean } \\
\text { Value of } \\
\text { DTPA- } \\
\text { Zn }\end{array}$} & \multicolumn{3}{|c|}{ Percent Sample Deficiency } & \multirow[t]{2}{*}{ NIV } & \multirow{2}{*}{$\begin{array}{c}\text { Fertility } \\
\text { Rating }\end{array}$} \\
\hline & & & & & Low & Medium & High & & \\
\hline 1 & Arakkonam & 108 & $0.3-4.9$ & 1.2 & 65.7 & 17.6 & 16.7 & 1.51 & Low \\
\hline 2 & Kaveripakkam & 224 & $0.1-6.7$ & 1.5 & 59.8 & 11.6 & 28.6 & 1.69 & Marginal \\
\hline 3 & Nemili & 228 & $0.4-7.7$ & 1.8 & 45.6 & 20.2 & 34.2 & 1.01 & Very low \\
\hline 4 & Arcot & 163 & $0.3-11.1$ & 1.8 & 33.1 & 34.4 & 32.5 & 1.99 & Marginal \\
\hline 5 & Timiri & 260 & $0.3-7.5$ & 1.4 & 57.3 & 21.2 & 21.5 & 1.65 & Low \\
\hline 6 & Gudiyattam & 172 & $0.4-8.1$ & 2.6 & 11.1 & 23.8 & 65.1 & 2.55 & High \\
\hline 7 & Katpadi & 82 & $0.5-5.9$ & 1.7 & 40.2 & 22.0 & 37.8 & 1.98 & Marginal \\
\hline 8 & K.V.Kuppam & 152 & $0.4-9.4$ & 2.0 & 23.0 & 32.9 & 44.1 & 2.22 & Adequate \\
\hline 9 & Peranambattu & 196 & $0.1-8.0$ & 2.1 & 20.9 & 29.6 & 49.5 & 2.30 & Adequate \\
\hline 10 & Jolarpet & 148 & $0.2-3.9$ & 1.0 & 79.0 & 14.1 & 6.76 & 1.93 & Marginal \\
\hline 11 & Kandili & 156 & $0.3-9.6$ & 2.2 & 18.6 & 25.6 & 55.8 & 2.38 & High \\
\hline 12 & Natrampalli & 115 & $0.2-7.0$ & 2.0 & 29.6 & 27.0 & 43.5 & 2.14 & Adequate \\
\hline 13 & Tirupatthur & 124 & $0.1-1.7$ & 0.5 & 98.4 & 1.6 & 0 & 1.02 & Very Low \\
\hline 14 & Alangayan & 98 & $0.6-11.4$ & 2.0 & 26.5 & 32.7 & 40.8 & 3.16 & Adequate \\
\hline 15 & Madhanur & 141 & $0.2-5.8$ & 1.1 & 73.1 & 16.3 & 10.6 & 1.38 & Low \\
\hline 16 & Anaicut & 152 & $0.4-9.4$ & 2.0 & 60.5 & 25.0 & 14.5 & 1.53 & Low \\
\hline 17 & Kaniyambadi & 104 & $0.5-4.6$ & 2.0 & 20.2 & 32.7 & 47.1 & 2.26 & Adequate \\
\hline 18 & Vellore & 76 & $0.1-7.9$ & 2.5 & 25.0 & 23.7 & 51.3 & 2.27 & Adequate \\
\hline 19 & Sholinganur & 168 & $0.3-5.9$ & 1.4 & 56.6 & 18.5 & 25.0 & 1.69 & Marginal \\
\hline \multirow[t]{2}{*}{20} & Walajapet & 143 & $0.1-10.9$ & 3.9 & 41.3 & 7.0 & 51.8 & 2.11 & Adequate \\
\hline & District & & $0.1-11.4$ & 1.8 & 44.3 & 21.9 & 33.9 & 1.86 & Marginal \\
\hline
\end{tabular}


Table.3 Range, Mean Values, Percent Sample Category, NIV and Fertility Rating of HSW-B for all the Blocks in Vellore District

\begin{tabular}{|c|c|c|c|c|c|c|c|c|c|}
\hline \multirow[t]{2}{*}{ S.No } & \multirow{2}{*}{$\begin{array}{l}\text { Name of the } \\
\text { Block }\end{array}$} & \multirow{2}{*}{$\begin{array}{c}\text { No. of } \\
\text { Samples } \\
\text { Collected }\end{array}$} & \multirow[t]{2}{*}{ Range } & \multirow{2}{*}{$\begin{array}{c}\text { Mean } \\
\text { Value of } \\
\text { HSW-B }\end{array}$} & \multicolumn{3}{|c|}{ Percent Sample Deficiency } & \multirow[t]{2}{*}{ NIV } & \multirow{2}{*}{$\begin{array}{c}\text { Fertility } \\
\text { Rating }\end{array}$} \\
\hline & & & & & Low & Medium & High & & \\
\hline 1 & Arakkonam & 108 & $0.12-2.6$ & 1.01 & 8.3 & 43.5 & 48.2 & 2.40 & High \\
\hline 2 & Kaveripakkam & 224 & $0.17-2.0$ & 0.78 & 5.8 & 83.0 & 11.2 & 2.05 & Adequate \\
\hline 3 & Nemili & 228 & $0.29-1.7$ & 0.90 & 3.5 & 59.2 & 37.3 & 1.45 & Low \\
\hline 4 & Arcot & 163 & $0.12-2.1$ & 0.57 & 45.4 & 39.3 & 15.3 & 1.70 & Marginal \\
\hline 5 & Timiri & 260 & $0.28-4.2$ & 0.57 & 49.2 & 35.4 & 15.4 & 1.69 & Marginal \\
\hline 6 & Gudiyattam & 172 & $0.10-1.5$ & 0.76 & 14.0 & 65.1 & 20.9 & 2.08 & Adequate \\
\hline 7 & Katpadi & 82 & $0.27-1.3$ & 0.76 & 4.9 & 84.2 & 11.0 & 2.06 & Adequate \\
\hline 8 & K.V.Kuppam & 152 & $0.10-2.8$ & 0.58 & 47.4 & 46.1 & 6.6 & 1.60 & Low \\
\hline 9 & Peranambattu & 196 & $0.31-2.1$ & 0.90 & 5.6 & 64.3 & 30.1 & 2.25 & Adequate \\
\hline 10 & Jolarpet & 148 & $0.10-3.0$ & 0.46 & 54.1 & 43.2 & 2.7 & 1.49 & Low \\
\hline 11 & Kandili & 156 & $0.10-5.9$ & 0.76 & 26.9 & 56.4 & 16.7 & 1.90 & Marginal \\
\hline 12 & Natrampalli & 115 & $0.10-7.4$ & 1.09 & 15.7 & 35.7 & 48.7 & 2.34 & High \\
\hline 13 & Tirupatthur & 124 & $0.10-3.0$ & 0.51 & 62.9 & 29.0 & 8.1 & 1.46 & Low \\
\hline 14 & Alangayan & 98 & $0.10-2.8$ & 0.49 & 56.1 & 38.8 & 5.1 & 1.51 & Low \\
\hline 15 & Madhanur & 141 & $0.10-2.1$ & 1.03 & 7.8 & 31.7 & 53.9 & 2.45 & High \\
\hline 16 & Anaicut & 152 & $0.10-2.8$ & 0.58 & 0.7 & 38.8 & 60.5 & 2.59 & High \\
\hline 17 & Kaniyambadi & 104 & 0.11-1.7 & 0.54 & 54.8 & 31.7 & 13.5 & 2.55 & High \\
\hline 18 & Vellore & 76 & $0.27-2.5$ & 1.13 & 3.7 & 36.8 & 59.2 & 1.59 & Low \\
\hline 19 & Sholinganur & 168 & $0.10-2.3$ & 0.41 & 72.0 & 22.0 & 6.0 & 1.35 & Low \\
\hline \multirow{2}{*}{20} & Walajapet & 143 & $0.10-2.1$ & 0.62 & 43.4 & 40.6 & 16.1 & 1.73 & Marginal \\
\hline & District & & $0.10-7.4$ & 0.72 & 29.1 & 46.6 & 24.3 & 1.91 & Marginal \\
\hline
\end{tabular}

Fig.1 Fertility Map for Available Zinc status in Vellore district of Tamil Nadu, India

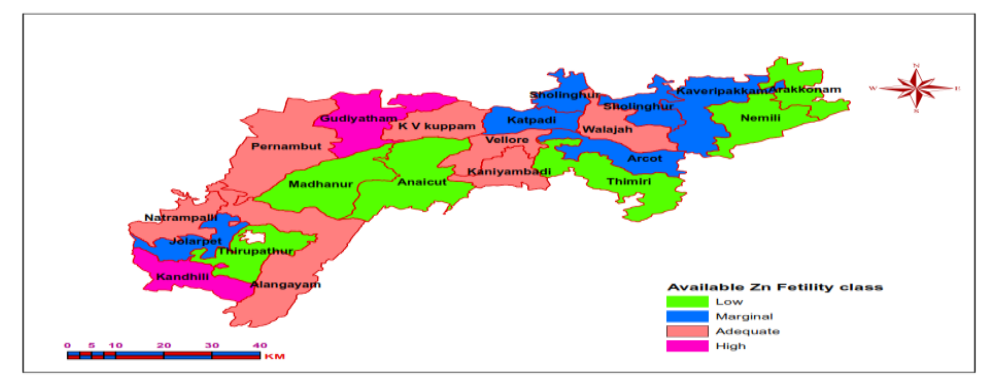

Fig.2 Fertility Map for Available Boron status in Vellore district of Tamil Nadu, India

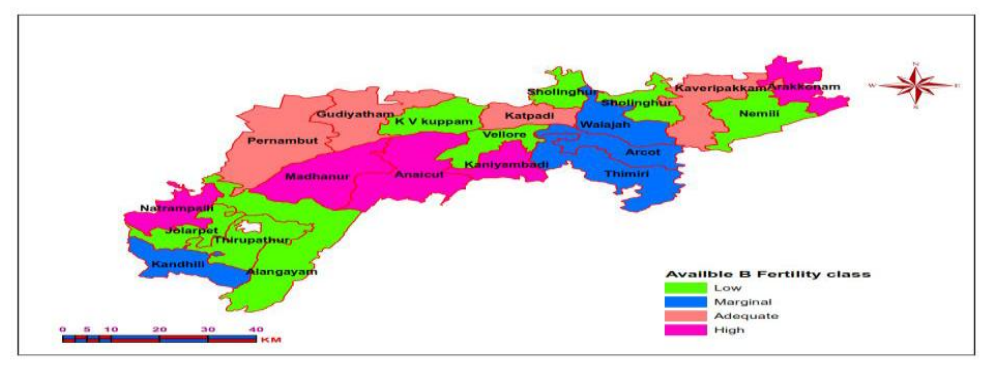


The lowest $\left(0.01 \mathrm{mg} \mathrm{kg}^{-1}\right)$ was noticed in the soils of Gudiyattam, K.V.Kuppam, Jolarpet, Kandili, Natrampalli, Tiruppathur, Alangayan, Madhanur, Anaicut, Sholinghur and Walajapet blocks. The low availability of boron might be due to the adsorption of boron on clay minerals and fixation via ligand exchange which probably reduced their availability (Keren et al., 1994). The HWS-B mean availability was sufficient in all the blocks except Sholinghur block.

Soil samples of Vellore district were found to be low in HWS-B to an extent of 29.1 per cent while 46.6 and 24.3 per cent of samples were found to be medium and high category respectively (Table 3 ). Specifically higher B per cent of high category samples was noticed in Anaicut $(60.5 \%)$, followed by Vellore $(59.2 \%)$ and Madhanur (53.9 \%). Higher per cent of medium category samples were noticed in Katpadi (84.2 \%) and Kaveripakkam (83\%) blocks and lower is noticed in Kaniyambadi (31.7 \%). The samples with highest percent of B deficiency was observed in Sholingur $(72.0 \%)$ followed by Thiruppathur (62.9\%) blocks and lower is noticed in Anaicut $(0.7 \%)$. Katpadi and Kaveripakkam blocks could be due to natural concentration of B in soils or continued use of irrigation water having high in soluble salts including B (Bradford et al., 1996). Further regular addition of organic/green manures might have also contributed to the higher $\mathrm{B}$ availability by adsorbing more in organic complex than in mineral constituents (Yermiyaho et al., 1988; Gu and Lowe, 1990; Datta et al., 2002; Nazif et al., 2006).

The nutrient index value for available $B$ ranged from 1.35 to 2.59 with fertility status of low to high and the district overall status (1.91) was marginal (Table 3). Among the blocks, the low B fertility status was registered in the blocks of Nemili, K.V.Kuppam, Jolarpet, Tiruppathur,
Alangayan, Vellore and Sholinghur. Arcot, Timiri, Kandili, Walajapet blocks were having marginal fertility status. Kaveripakkam, Gudiyattam, Katpadi, Pernambattu, blocks were falls under adequate soil fertility status. Arakkonam, Natrampalli, Madhanur, Anaicut, Kaniyambadi were having high soil fertility status. Fertility map was prepared for B based on nutrient index values using Arc GIS software (Figure 2).

In conclusion the wide spread deficiency of $\mathrm{Zn}$ in Vellore district showed that $\mathrm{Zn}$ is the most important limiting factor for sustainable productivity and corrective measures and proper management practices are required to avoid increase in the magnitude of the problem. The findings of Shyempura and Seghal (1995) and Katyal and Datta (2004) also subscribe to this view. The status of $\mathrm{Zn}$ and $B$ depicts that it may acquire the status of deficiency in future due to exploitation of the nutrients by intensive farming. Hence care should be taken to maintain the levels of available $\mathrm{Zn}$ and $\mathrm{B}$ in the soil to overcome the increasing deficiency in near future. The use of organic manures or inorganic micronutrient fertilizers can be used to increase the micronutrient availability.

\section{References}

Berger, K.C. and Truog, E. (1946) Boron availability in relation to soil reaction and organic matter content. Soil Science Society of America Journal 10, 113116.

Bradford, G.R., Chang, A.C., Page, A.L., Frampton, J. A. and Wright, H. (1996) Background concentrations of trace and major elements in California soils. Berkely: Kearncy Foundation of Soil Science, Division of Agriculture and Natural.

Datta, S.P., Rattan, R.K., Suribabu, K. and 
Datta, S.C. (2002) Fractionation and colorimetric determination of boron in soils. Journal of Plant Nutrition and Soil Science 165, 179-184.

$\mathrm{Gu}$, B. and Lowe, L.E. (1990) Studies on the adsorption of boron on humic acid. Canadian Journal of Soil Science 70, 305-311.

Katyal, J.C. and Datta, S.P. (2004) Role of micronutrients in ensuring the optimum use of macronutrients. Paper presented at IFA International symposium on micronutrients, held at New Delhi, India during February 23-25.

Keren, R., Grossl, P.R. and Sparks, D.L. (1994) Equilibrium and kinetics of borate adsorption - desorpt ion on pyrophyllite in aqueous suspensions. Soil Science Society of America Journal 58, 1116-1122.

Lindsay, W.L. and Norvell, W.A. (1978) Development of DTPA soil test for zinc, iron, manganese and copper. Soil Science Society of America Journal 42, 421-428.

Mueller, T.G., Hartsock, N.J., Stombaugh, T.S., Shearer, S.A., Cornelius, P.L. and Barnhise, R.I. (2003) Soil electrical conductivity map variability in limestone soil overlain by loess. Agronomy Journa 95, 496-507.

Nazif, W., Perveen, S. and Salem, I. (2006) Status of micronutrients in soils of district Bhimber (Azad Jammu and
Kashmir). Journal of Agricultural and Biological Science 1(2), 35-40.

Ramamoorthy, B. and Bajaj, J.C. (1969) Available N, P and $\mathrm{K}$ status of Indian soils. Fertilizers News 14, 24-26.

Sharma, J.C. and Chaudhary, K. (2007) Vertical distribution of micronutrient cations in relation to soil characteristics in lower Shiwaliks of Solan district in north-west Himalayas. Journal of the Indian Society of Soil Science 55, 4044.

Shyampura, R.L. and Sehgal, J. (1995) Soils of Rajasthan for optimizing land use. NBSS public, 51 (Soil of India series) NBSS \& LUP Nagpur $76+6$ sheets of soil map.

Siba, P., Datta, Rattan, R.K., Suribabu, K. and Datta, S.C. (2002) Fractionation and calorimetric determination of boron in soils. Journal of Plant Nutrition and Soil Science 165,179 - 184.

Takkar, P.N., Nayyar, V.K., Bansal, R.L., Dwivedi, R.S. and Manna, M.S. (1997) Annual progress report of ICAR coordinated micronutrient scheme 199697. Punjab Agricultural University, Ludhiana.

Yermiyaho, U., Keren, R. and Chen, Y. (1988) Boron sorption on composted organic matter. Soil Science Society of America Journal 52, 1309-1313.

\section{How to cite this article:}

Soniya Purma, D. Muthumanickam and Reshma, M. R. 2021. Delineation and Mapping of Soil Available Zinc and Boron Status in Soils of Vellore District of Tamil Nadu, India. Int.J.Curr.Microbiol.App.Sci. 10(01): 3347-3353. doi: https://doi.org/10.20546/ijcmas.2021.1001.393 